University of Rhode Island

DigitalCommons@URI

Open Access Master's Theses

1997

\title{
An Exploratory Analysis of the Relationship of Leaders' Gender to Multiple Aspects of Organizational Functioning in Community Coalitions
}

llene Klein

University of Rhode Island

Follow this and additional works at: https://digitalcommons.uri.edu/theses

\section{Recommended Citation}

Klein, Ilene, "An Exploratory Analysis of the Relationship of Leaders' Gender to Multiple Aspects of Organizational Functioning in Community Coalitions" (1997). Open Access Master's Theses. Paper 1642. https://digitalcommons.uri.edu/theses/1642

This Thesis is brought to you for free and open access by DigitalCommons@URI. It has been accepted for inclusion in Open Access Master's Theses by an authorized administrator of DigitalCommons@URI. For more information, please contact digitalcommons-group@uri.edu. 
$3>-1$

$2+1$

65

$190 \%$

\section{AN EXPLORATORY ANALYSIS OF THE RELATIONSHIP OF LEADERS'}

GENDER TO MULTIPLE ASPECTS OF ORGANIZATIONAL

FUNCTIONING IN COMMUNITY COALITIONS

BY

ILENE KLEIN

A THESIS SUBMITTED IN PARTIAL FULFILLMENT OF THE

REQUTREMENTS FOR THE DEGREE OF

MASTER OF ARTS

IN

PSYCHOLOGY

UNIVERSITY OF RHODE ISLAND

1997 


\begin{abstract}
This study explored the relationship of leaders' gender to multiple aspects of organizational functioning. It focused on perceptions of leadership style (the extent to which leaders were task focused and interpersonally focused), social climate of the groups (inclusion/cohesion of the group and the task focus of the group), and specific characteristics of the group members (member satisfaction with the group and member commitment to the group).

Data were collected from members of 32 substance abuse prevention task forces across the state of Rhode Island, $(\mathrm{N}=180)$. The independent variable of leaders' gender in this study was defined as a shared characteristic of the coordinator and the chair of the task forces. The 32 task forces were divided into three groups (women leaders, men leaders, mixed gender leaders). Two sets of ANOVAs were performed using SAS Proc MIXED, a statistical procedure that accounts for nested data. One set added respondent gender to leaders' gender as a second independent variable, while the other set added gender composition of the group to leaders' gender and as a second independent variable. The same dependent variables were used in each set of analyses.

Differences were found across the three different gender led groups on one dependent variable, member commitment to the group, only in the first set of analyses. Members from groups led by men had lower commitment scores than members from groups led by women and members from mixed gender led groups. In addition, differences among men and women respondents on member commitment scores were found. Men in general, had lower scores on member commitment to the group than women. These results suggest that future research in the area of leadership and gender should include measures of member commitment.
\end{abstract}




\section{Acknowledgments}

I would first like to thank Paul Florin, Ph.D. for his guidance and support. This thesis would not have been possible without his help. I would also like to thank Bernice Lott, Ph.D. for her advice and support, and Elizabeth Cooper, Ph.D. for her valuable feedback and information. Lastly, I wish to extend my appreciation to Jerry Cohen, Ph.D. for spending time consulting with me about the statistics used in this thesis. 


\section{Table of Contents}

Abstract

Acknowledgments

List of Tables

Introduction

Relationship between leadership and gender

Methodology

Results

Discussion

Tables $1-6$

List of references

Appendix A

Appendix B

Bibliography
Page ii

Page iii

Page v

Page 1

Page 2

Page 12

Page 17

Page 18

Page 23 - 28

Page 29

Page 32

Page 41

Page 44 


\section{List of Tables}

Table 1 Summary of Dependent Variables from Cited Studies Page 23

Examining the Effects of Leader Gender

Table 2 Demographic Characteristics of the Sample Page 24

Table 3 Number of Respondents with Female, Male, and Mixed Page 25

Gender Leaders

Table 4 Correlation's Among the Dependent Variables Page 26

$\begin{array}{lll}\text { Table } 5 & \text { Least Square Means and Standard Errors for } & \text { Page } 27\end{array}$

Analysis \#1

Table 6 Least Square Means and Standard Errors for $\quad$ Page 28

Analysis \#2 


\section{Introduction}

Community coalitions have become increasingly important in the field of prevention and health promotion. As a result, variables related to their functioning and effectiveness are beginning to be studied (Florin, Mitchell, \& Stevenson, 1993). Leadership is one of these variables. This study looked at the relationship between leaders' gender and multiple aspects of organizational functioning in community coalitions.

The literature on the relationship between leaders' gender and organizational functioning is very complex. There are several underlying theories, none of which have been consistently supported by the research (Eagly, Karau, \& Makhijani, 1995). Contradictory results and analysis problems are commonplace in the literature; and as a result, there is no clear-cut decision on the exact relationship between leaders' gender and organizational functioning.

The contradictory results and problems in the literature may be due to the fact that these studies have been conducted in multiple settings (i.e. business, military, social service agencies), constructs have been operationalized differently (e.g. effectiveness, satisfaction), and failure to use statistical analyses that controlled for the complexity of the data. This study addressed these problems by looking at leaders within a single setting (voluntary organizations), focusing on multiple aspects of organizational functioning that were clearly operationalized, and by using a statistical analysis that accounted for the hierarchical nested nature of the data.

This study was exploratory. No hypothesis or predictions were made because the literature does not provide enough empirical support for any one underlying theory, and the empirical evidence is very contradictory. In addition, leader gender in this study was operationalized in an unusual way to include two individuals, not just one, making comparisons with previous literature difficult. 
This thesis first describes the complex relationship between leadership and gender. It then addresses the theories proposed to explain this relationship. Results of studies in this area are then presented along with some possible explanations for contradictory results. Lastly, the relationship between a leader's gender and organizational commitment are addressed.

\section{The relationship between leadership and gender}

The relationship between leadership and gender is very complex. This may be because the term leadership has many definitions, and these definitions mean different things in different contexts. Denmark (1993) argues that there is no clear-cut definition of leadership that includes all circumstances because the emergence of leaders is often situational, thus resulting in leaders who are sometimes permanent and sometimes temporary.

Theories of leadership have ranged from those that emphasize personal characteristics of an individual (i.e., only a select group of people possesses these skills) to those that an emphasize situational or environmental factors (i.e., difficult situations create leaders) to a number of theories that propose an interaction between individuals and the environment (i.e., who becomes a leader depends upon situational demands).

Denmark (1993) notes that much of the research on leadership has focused on men, and that only in the last 10 years or so have researchers begun to study women in leadership roles. This may be due to the fact that women were not typically in these roles or expected to be in them. There is now greater recognition of women in leadership positions and, as a result, many researchers have begun to explore the relationship between an individual's gender and his/her behavior in a leadership role.

The literature on gender and leadership has generally focused on four areas of leadership. Researchers have looked at possible gender effects in the evaluation of leaders, in leadership styles, in the emergence of leaders in initially leaderless groups, and in the effectiveness of leaders. These studies typically fall into two categories: laboratory 
studies (usually conducted with college students in a controlled setting), and organizational studies (usually conducted in the field using managers/supervisors of different types of organizations or groups).

Various types of data have been collected to look at the relationship between gender and leadership. These include self-report measures from the leaders themselves, self-report measures from group members, observational data from an independent third party, and group/organizational outcome data (e.g., productivity level). Self-report measures from followers/subordinates have focused on their perceptions of leadership behavior and indirect measures of leader's behavior. Some studies have asked members to evaluate a leader's behavior (e.g., to rate the leader's competence in performing a task) while others have asked more indirect questions (e.g., to rate a member's satisfaction with the group) and drawn conclusions about a leader's behavior from this information. The data collected are dependent upon the research question being asked and the underlying theory guiding the research.

Theories concerning leadership and gender

In a series of meta-analytic studies concerned with the relationship between gender and different aspects of leadership, Eagly and associates identified four main theories. These are: social-role theory or gender-role congruency (Eagly et al., 1995), structural perspective (Eagly \& Johnson, 1990), selection bias or differential selection, and contingency theories (Eagly et al., 1995).

Social-role theory, or gender-role congruency theory, considers expectations about behavior for women and men that are consistent with culturally defined gender roles. It proposes that there is a general tendency for people to behave in ways that are consistent or congruent with their culturally defined gender roles. This may be due to social pressures external to the individual and/or to cultural expectations that the individual has internalized. Social-role theory anticipates that leadership roles may be problematic for women due to the stereotypically male qualities associated with the leadership role. It 
predicts that women in these roles may be perceived differently than men in the same role due to the incongruity of the female gender role and the leadership role. In addition, it predicts that certain leadership roles will be aligned more with one gender than another. For example, a nursing supervisor would be a leadership role that is more consistent with a female gender role, and a military officer would be a leadership role more consistent with a male gender role. Hypotheses based on this theory predict differences in the evaluation of men and women leaders, and differences in the perceived or actual effectiveness of men and women leaders, to the extent that the leadership role is congruent or incongruent with the individual's gender.

Eagly and Johnson (1990) note that the structural perspective approach to the relationship between leadership and gender emphasizes the formal structure of the group or organization, rather than the gender of the leader. Within the structure of the group, specific roles are given different amounts of status and power, and it is an individual's role within the group that dictates the amount of status and power she or he has, not the particular individual. This theory does not predict any differences between men and women leaders in the same leadership role to the extent that they are equivalent in status and power. This theory also predicts that the leadership role dictates a leader's behavior, regardless of gender. It is expected that people in similar roles will behave in similar ways because their role dictates their behavior, not their individual characteristics. There should not be any gender difference between men and women leaders in similar leadership roles, because the leaders of a group are selected according to a set of criteria relevant to the group. These criteria are blind to gender or other individual characteristics, and men and women are selected into leadership roles according to the same set of criteria. It is further expected that individuals are socialized into their leadership roles early in their careers with the group or organization, and that this socialization process eliminates or reduces any individual differences between people in similar positions. 
Another theory that has been used to make predictions about the relationship between gender and leadership is the differential selection or selection bias theory. This theory rests on the assumption that women face more barriers than men in obtaining leadership positions. Eagly et al. (1995) suggest that women who are in leadership roles may be more qualified and competent than men in the same roles because they had to overcome more obstacles. Therefore, hypotheses based on this theory predict that there would be differences between women and men in the same leadership roles. Women leaders would be perceived as more effective in these roles by their subordinates, and they would actually being more effective in these roles.

The last major theoretical base that has been used to understand the role of gender in leadership are the contingency theories of leadership. These are a set of theories that look primarily at an individual's style of leading in interaction with aspects of a situation (Eagly et al., 1995). These theories state that the relationship between a leader's effectiveness and leadership style is moderated by situational variables. So, individuals may differ in the effectiveness of their roles to the extent that they are using different leadership styles in different situations. In relation to gender, this approach examines the question of differing leadership styles for men and women. There are no predictions about gender differences in leadership styles, only about the effectiveness of men and women leaders in specific situations based on their particular individual style of leading. Research on leadership styles

Research on leadership styles has generally explored two types of styles. These styles have many different names but they all tend to focus on the same two aspects of behavior. The first style places greater emphasis on task accomplishments (i.e., organization of activities to perform specific tasks) while the second style places greater emphasis on the maintenance of positive interpersonal relationships among the members of the group/organization (i.e., tending to the morale and welfare of people in the group). The first of these has been called task style or task orientation (Eagly \& Johnson, 1990), 
directive leadership (Eagly et al., 1995), and initiating structure ( Petty \& Lee, 1975 ), while the second has been called interpersonal orientation (Eagly \& Johnson, 1990), participative leadership (Eagly et al., 1995), and consideration (Petty \& Lee, 1975). A number of studies have explored the relationship between these two styles and gender stereotypes, and the question of whether or not women and men are more likely to adopt one style over the other. Contingency theory based research has also looked at specific situations in which women or men adopt one style over the other. Empirical findings

Given the different underlying theoretical orientations, different types of data collected, and different methods used to collect data, it is not surprising that there is no clear consensus about the effect of leader's gender on leadership style and organizational functioning. In fact, research findings are somewhat contradictory as can be seen in Table 1 ; no one theory has consistently been supported.

Gupta, Jenkins, and Beehr (1983); Korabik, Baril, and Watson (1993); and Eagly et al. (1992) have all found a gender difference in subordinate evaluation of leaders (overall competence ratings of a leader's ability to do the job), while Day and Stogdill (1972) found no gender difference in subordinate evaluation of women and men leaders. Gupta et al. (1983) found that evaluations of women leaders were more positive than those of men leaders. Korabik et al. (1993) found that women and men leaders who used similar leadership styles were evaluated differently by subordinates. Eagly et al. (1992) found a small overall tendency for women leaders to be evaluated less favorably than men leaders. Day and Stogdill (1972) found that women and men leaders who occupied parallel positions and performed similar functions were evaluated similarly by their subordinates.

Some studies have found a gender difference in the effectiveness of leaders (i.e., a subordinate's rating of a leader's effectiveness in performing a specific aspect of their job) (Rojahn \& Willemsen, 1994; Korabik et al., 1993; ), while others have not (Day \& 
Stogdill, 1972; Komives, 1991; Rice et al., 1984; Petty \& Bruning, 1980; Eagly et al., 1995). Both Rojahn and Willemsen (1994) and Korabik et al. (1993) found that women and men leaders who behaved in a gender incongruent way were perceived as being less effective. Day and Stogdill (1972) and Komives (1991) found that women and men leaders had similar effectiveness ratings from their subordinates. Petty and Bruning (1980) found that women and men leaders were similarly effective in using "interpersonal" and "task focused" leadership styles. Rice et al. (1984) found that leaders of both genders in a military setting were equally "successful" when rated by their subordinates. Eagly et al. (1995) found no overall gender difference in the rated effectiveness of leaders in their meta-analysis of the literature.

The same contradictory results are found in studies examining leadership styles. Some have found a gender difference ( Bartol \& Wortman, 1975; Petty \& Bruning, 1980; Eagly \& Johnson, 1990) while others have not (Korabik et al., 1993; Rice et al.., 1984). Bartol and Wortman (1975) found that women leaders were perceived as higher on "task focused" leadership style than men leaders. Petty and Bruning (1980) found that women leaders were rated as showing higher levels of consideration than men leaders in the same role when rated by their subordinates in three of six job classifications. Eagly and Johnson (1990) concluded in their meta-analysis that women's leadership styles emphasize both task accomplishment and interpersonal relationships to a "slightly greater" extent than men's styles. They found a gender difference in the leadership styles of leaders in laboratory studies but not in organizational studies. Korabik et al. (1993) found no differences in conflict management styles (as indicated by self-report data, subordinate data, and content analysis) between experienced men and women supervisors during a role play exercise. Rice et al. (1984) found no gender differences in leadership process.

In subordinate/member satisfaction measures, Petty and Lee (1975) found a gender difference but Komives (1991) and Bartol and Wortman (1975) did not. Petty and Lee (1975) found that subordinates with supervisors who had high ratings on "interpersonal 
leadership style" reported greater job satisfaction. This relationship was significantly higher for subordinates with women supervisors than those with men supervisors. Komives (1991) found no difference in job satisfaction between resident assistants supervised by a woman or man in university residence halls. Bartol and Wortman (1975) found no difference in the satisfaction of members led by women or men.

\section{Gender of the respondent}

Some studies have looked at the gender of the those doing the evaluation of the leader. Many organizational studies have found that the gender of the evaluator or subordinate was significantly related to the overall evaluation of leaders (Bartol \& Wortman, 1975; Gupta et al., 1983; Rice et al., 1984; Eagly et al., 1992), the evaluation of the effectiveness of leaders (Rojahn \& Willemsen, 1994; Eagly et al., 1995), and self-reported member satisfaction with their job/position (Petty \& Lee, 1975; Bartol \& Wortman, 1975; Klein, Kossek, \& Astrachan, 1992). Gupta et al. (1983) found that leader evaluations made by subordinates of the other gender tended to be higher than those made by subordinates of the same gender. However, in their meta-analysis, Eagly et al. (1992) found the opposite. They found that women leaders were more devalued than men leaders when their evaluators were men. Rice et al. (1984) found that women subordinates were more favorable in their overall ratings of leaders than men subordinates. Bartol and Wortman (1975) found that women were more favorable than men in their evaluations of leaders, and that women gave higher satisfaction ratings than men. Rojahn and Willemsen (1994) found support for the gender role congruency theory from men subjects but not from women respondents. Men perceived gender role incongruent leaders to be less effective than gender role congruent leaders, while women did not. Eagly et al. (1995), in their meta-analysis, found that the gender of the rater was correlated with a study's outcome. The higher the proportion of men among the raters, the more the raters' effectiveness ratings favored men over women. Petty and Lee (1975) found that "task focused leadership style" by women supervisors was negatively 
associated with satisfaction scores made by men but positively associated with satisfaction for women. Klein et al. (1992) found that women with women leaders reported a more positive affective experience from a residential training program than all other gender pairs (i.e., men with male leaders, men with female leaders, women with male leaders).

Possible explanations for contradictory results

Why is there so much inconsistency in the literature and so little clear support for the underlying theories? Perhaps because the theories are either too broad or too specific For example, gender-role congruency theory predicts gender differences to the extent that a leader's behavior or leadership role is congruent or incongruent with the individual's gender. This may be too broad a generalization and may hold for certain situations but not others. For example, Petty and Lee (1975) found support for the gender-role congruency theory, while Rice et al. (1984) did not. Petty and Lee (1975) found that men group members had lower satisfaction scores with women supervisors who had high ratings in initiating structure. Rice et al. (1984) found no difference in subordinate descriptions of women and men leaders on six categories of "leadership process" that are associated with sex-role stereotypes (communication, influence tactics, bases of social power, etc.). A possible reason for these contradictory results may be because the Rice et al. (1984) study was done in a military setting, while the Petty and Lee (1975) study was conducted in a university setting. Thus, the gender-role congruency theory may be a more situation specific theory than a broad all inclusive one.

On the other hand, Eagly et al. (1995) believe the structural perspective may be too specific. They do not dismiss the theory entirely but rather enlarge it to include the concept of gender-role spillover effects. These are defined as gender based expectations about behavior that get carried over into the workplace. So, even though women and men in similar leadership roles may posses the same qualifications and abilities, observers may report some gender based expectations about the leader's behavior. Eagly et al. (1995) 
suggest that this expanded structural perspective is a better theory to test, but have found no empirical evidence to support it.

Another explanation for these contradictory results may be related to the setting of the studies, regardless of the theory being tested. Rice et al. (1984) found no gender differences in leadership styles while Bartol and Wortman (1975) did find gender differences. This may be because the Rice et al. (1984) study was conducted in a military setting while the Bartol and Wortman (1975) study was conducted in a psychiatric hospital.

Another problem is that studies use different operationalizations of terms like effectiveness, evaluation, and satisfaction. For example, in studies exploring differences in the evaluation of leaders, evaluation has sometimes meant self-report measures from leaders themselves and sometimes self-report measures from subordinates. Effectiveness of a leader is also a term that has had different meanings in different studies. Some studies equate this with a specific leadership style (Day \& Stogdill, 1972), while others conceptualize this as more of an outcome measure, where the leader's ability to meet group or organizational goals is studied (Rojahn \& Willemsen, 1994). Satisfaction also means different things in different studies. In some studies satisfaction means an individual's satisfaction with his or her job/role in a group, while in others it means an individual's satisfaction with different aspects of the leader's style. Differences in the way variables have been operationalized make it difficult to summarize results across studies or to draw firm conclusions.

Another possible explanation for the diversity of results in this area has to do with the statistical analyses used in the studies. Many organizational studies use existing groups to study differences related to leader's gender. Data of this nature are said to be nested because an individual score is nested within a particular group (i.e., with a specific leader) that is nested within a specific experimental condition (e.g., groups with women leaders). If the nested nature of the data is not accounted for in the analysis used, there 
can be an inflated Type 1 error rate resulting in rejection of a true null hypothesis (Murray \& Wolfinger, 1994). This means that the statistical analysis may not be suitable for detecting subtle gender differences that may be present. All previous research in this area has failed to address this statistical analysis issue. None of the studies cited considered the nested nature of the data or used statistical procedures to compensate for this type of design. As a result, studies that were investigating subtle gender effects in leadership roles may not have been able to detect any because of the statistical analyses that was performed.

Organizational commitment and leadership gender

The commitment of members to an organization has generally not been studied in relationship to the gender of its leaders. Organizational commitment has been conceptualized as having two main components: attitudinal commitment and continuance or calculated commitment. Aven, Parker, and McEvoy (1993) define attitudinal commitment as a "form of moral involvement that represents a positive and intense involvement in, attachment to, and identification with the goals and values of the organization" (p. 64). Mowday, Porter, \& Steers (1982) further explain that it is characterized by three factors: "a strong belief in and acceptance of the organization's goals and values; a willingness to exert considerable effort on behalf of the organization; and a strong desire to maintain membership in the organization" (p.27). Continuance or calculated commitment focuses more on the individual's perception of the invested costs that bind her/him to the organization (Aven, Parker, \& McEvoy,1993). Mathieu and Zajac (1990) explain that calculated commitment is the extent to which individuals are bound to an organization because they have "side bets or sunk costs (i.e. pension plan)" (p.172) invested in it and cannot afford to separate themselves from the organization.

Graddick and Farr (1983) examined attitudinal organizational commitment along with job involvement, role conflict, treatment on the job, and involvement in professional organizations, with members from three professional societies (American Psychological 
Association, American Physical Society, and Society of Industrial and Applied Mathematicians). They found that men were more committed to their organizations than women. A similar gender difference was found by Aranya et al. (1986) with accountants working in professional organizations. In their meta-analysis of antecedents, correlates, and consequences of organizational commitment, Mathieu and Zajac (1990) found a slight relationship between gender and attitudinal commitment but in a different direction; they found that women were more committed than men. A different meta-analysis that focused entirely on gender and attitudinal commitment done by Aven et al. (1993) found no evidence for a gender difference in attitudinal commitment.

Mathieu and Zajac (1990) also found that specific leader characteristics (leader communication, participatory leadership, and "task focused and interpersonal" leadership styles) were positively related to the commitment of members. Leaders who had high scores on these characteristics had members with high commitment scores. Organizational commitment (specifically attitudinal commitment) has been studied in relation to respondent gender and in relation to leadership styles but the relationship between the gender of the leader of an organization and the commitment of members of that organization has generally not been examined.

Organizational commitment was examined as a variable in this study because of its importance in voluntary organizations. Voluntary organizations rely on the participation of members; if members are not committed they will most likely not participate consistently in an organization. Therefore, even though commitment has generally not been used as a measure in leadership studies, it was included in this study because of the setting in which leadership was explored.

\section{Methodology}

\section{Setting and Context:}

The data used in this study were collected as part of an independent evaluation of the Communities United for Prevention project (CUP). CUP is a federal demonstration 
project funded by the Center for Substance Abuse Prevention (CSAP). It is composed of Rhode Island Substance Abuse Prevention Act Task Forces that were established in 1989 under the Rhode Island Substance Abuse Prevention Act (RISAPA). RISAPA authorized each community in the state to create broad-based alcohol and other drug prevention task forces to plan and implement prevention programs in their communities. The job of each of these task forces was to tailor their prevention efforts to the unique multiple risk factors within their community. To accomplish this, members from various sectors within their communities (local government, police, schools, concerned citizens) were recruited into the task forces.

The evaluation component of CUP is being conducted by the Community Research and Services Team at the Center for Alcohol and Addiction Studies of Brown University. The evaluation team collects various types of data from these task forces through a mailed survey to all task force members, face to face interviews with task force leaders, monthly telephone interviews with task force leaders, and telephone interviews with key informants in the various communities.

\section{Instrument}

The instrument used in this study was the CUP 1996 Task Force member survey. The survey contains 127 items that assess demographics, evaluations of the task force leaders, member satisfaction, member participation, and many other constructs (see Appendix A). It also included an informed consent form. This instrument was mailed to all the members of the 35 community task forces in Rhode Island during the summer of 1996 after it was granted approval from the Institutional Review Board of Brown University.

\section{Participants}

The CUP member survey was sent to the 779 known members of the 35 community task forces across the state of Rhode Island during the summer of 1996 . It was returned in self-addressed stamped envelopes by 252 members, giving an approximate 
response rate of $32 \%$. Table 2 presents a demographic description of the respondents. Sixty-two percent of the respondents were women, and $38 \%$ were men. Ages of the respondents ranged from 14 to 77 years old, with the majority (68\%) falling within the age range of 30 to 50 . The amount of time respondents had served on their respective task forces ranged from 3 months to 8 years, with $54 \%$ of the members having served on their task force between 2 and 6 years. The average number of hours per month these members dedicated to task force activities was 14 hours and, as a group, on the average, the respondents attended over $70 \%$ of task force meetings held during the previous 12 months. Thus, the respondents represent the most active members of these organizations.

The respondents are probably not representative of the citizens of Rhode Island. The majority $(76 \%)$ had received a college degree or a more advanced degree; $62 \%$ were employed full time; $78 \%$ had an annual income of $\$ 30,000$ or more; $73 \%$ were married; and $83 \%$ of the respondents were homeowners. Most of the respondents (93\%) identified themselves as White, $3 \%$ as African-American, $1 \%$ as Asian-American, $1 \%$ as Native-American, and $1 \%$ as either Latino or Other. This sample, however, appears typical of voluntary municipal level organizations (McPerson \& Smith-Lovin, 1986). Variables

The focus of this study was the effect of leaders' gender on multiple aspects of organizational functioning in these community coalition groups. These community task forces provided an opportunity to study leadership in a unique way because the majority of these task forces have two leaders, a paid staff coordinator and an elected chair of the task force. In theory, the coordinator is supposed to act as a resource/referral person assisting the task force, while the chair acts as a facilitator for the functioning of the group. In practice, however, these roles are not well differentiated. In some cases the coordinator and chair co-lead the task force, while in others the coordinator or the chair may have the primary leadership role. Therefore, for the purpose of this study, the independent variable of leaders' gender was defined as a shared characteristic of the coordinator and the chair 
of the task force. The 35 task forces were divided into three groups: those having women leaders (as both coordinator and chair); those having men leaders (as both coordinator and chair); and those having mixed gender. Table 3 presents the number of groups in each of these categories. Task forces that had only one leader $(n=3)$ were not included in this study.

In addition to the gender of the leaders, there were two other independent variables. One was the gender of the respondent and the other was a variable representing the gender composition of the members of each task force. The task forces were categorized as having a majority of women members or a majority of men members. Those task forces that had an equal number of women and men, were labeled as having a majority of female members. This decision was based on the finding that organizations with more women in them tend to be viewed as female dominated even if there is an equal number of men in the organization (Cooper, Doverspike, \& Barrett, 1985)

The eight dependent variables (multiple aspects of organizational functioning) were: members' perceptions of the coordinator's task focus leadership style; members' perceptions of the coordinator's interpersonal leadership style; members' perceptions of the chair's task focus leadership style; members' perceptions of the chair's interpersonal leadership style; members' perceptions of involvement/inclusion in the task force; members' perceptions of the task focus in the task force; members' satisfaction with the task force; and members' commitment to the task force. Appendix B presents the items in the survey that tapped each of these variables.

Perception of the leadership style was assessed by eight survey items on which respondents rated, on a scale from 1 (strongly disagree) to 5 (strongly agree), their level of agreement with specific statements regarding the leadership styles of the coordinator and the chair. Respondents rated the coordinator and the chair separately on the each of four statements. These statements fell into two categories reflecting the two types of leadership styles studied in the literature: task focus ( e.g., "The coordinator staffs the task 
force in an orderly and efficiently manner") and interpersonal focus (e.g., "The chair makes sure everyone is listened to in the meetings"). Two scores were obtained for both the chair and the coordinator, one representing the task focus leadership style and another representing the interpersonal leadership style. These composite scores ranged from 1 to 5.

The task force involvement/inclusion score could range from 1 to 5 . It was derived from 5 items on which respondents rated their level of agreement, on a scale from 1 (strongly disagree) to 5 (strongly agree), with statements about the involvement of members (e.g., "Everyone is involved in discussions, not just a few") and inclusion of members (e.g., "The group has a feeling of cohesiveness and team spirit") in the operation of the task force. These five items loaded onto one factor and the scale had a Cronbach's alpha coefficient of .85 .

The task focus score could range from 1 to 5 . This score was derived from 5 items on which respondents rated their level of agreement, on a scale from 1 (strongly disagree) to 5 (strongly agree), with statements about order (e.g., "The task force is disorganized and inefficient") and structure within the task force (e.g., "The group needs more formalization and structure"). These five items loaded onto one factor and the scale had a Cronbach's alpha coefficient of 84 .

The member's satisfaction with the task force score could range from 1 to 5 and was derived from 6 items on which respondents rated their level of satisfaction, on a scale from 1 (very dissatisfied) to 5 (very satisfied), with different aspects of the task force (e.g., "The degree of member involvement with program implementation") and in being a member of the task force (e.g., "Personal experience as a task force participant"). Preliminary analyses found that these 6 items loaded onto one factor that accounted for $72 \%$ of the variance, and the Cronbach's alpha coefficient was .92 .

The member's commitment to the task force score ranged from 1 to 5 . This measure of attitudinal commitment, was derived from 4 items on which respondents rated 
their level of agreement, on a scale from 1 (strongly disagree) to 5 (strongly agree), with statements of pride in (e.g., I am proud to tell others I am on the task force") and commitment to the task force (e.g. "I feel strongly committed to the task force"). These four items loaded onto one factor, and the scale had a Cronbach's alpha coefficient of .86 .

Four variables assessed the extent to which members believe that their leaders were task focused and/or interpersonally focused. Thus, they are measures of leadership style. The task force cohesion and task focus variables are measures of the social climate of the group; they focus on specific qualities of the task force. The satisfaction variable and commitment variable are measures of leadership effectiveness.

Analysis

The major analysis that was performed was ANOVA using SAS Proc MIXED, a statistical program that compensated for the nested nature of the data. Multiple ANOVAs were performed as opposed to a MANOVA because Proc MIXED is a univariate procedure. A MANOVA seemed to be a more appropriate analysis due to the multiple dependent variables in this study, however the multilevel nature of the data (i.e., the nesting effect) was given greater priority over the multivariate nature of the questions being asked. Thus, multiple univariate ANOVAs were performed using Proc MIXED.

Two sets of eight $3 \times 2$ ANOVAs were performed for a total of sixteen ANOVAs. The first set of analyses used leaders' gender and gender of the respondent as independent variables. The second set of analyses used leaders' gender and the gender composition of the group (majority female or majority male) as independent variables. The same eight dependent variables were used in both sets of analyses.

\section{Results}

Table 4 presents the results of correlation's among the eight dependent variables. As can be seen, all the dependent variables were highly correlated with each other.

Tables 5 and 6 present the results of the sixteen ANOVAs performed using SAS Proc MIXED. As can be seen by these tables, there was a significant effect for only one 
dependent variable, commitment; and this effect was found only in one set of analyses. When leader gender and respondent gender were independent variables, significant main effects of leader gender, $(\mathrm{E}(2,145)=3.91, \mathrm{p}<.05)$, and respondent gender, $(\mathrm{E}(1,145)=$ $3.76, p=.05$ ) were found. Follow-up Tukey tests indicated that the mean commitment score of individuals from male led task forces was significantly lower than both the mean commitment score of individuals from female led task forces and the mean score of individuals from mixed gender led task forces. These analyses also found that women and men significantly differed in their commitment to their respective task forces. The mean commitment score for men respondents was significantly lower than the mean commitment score for women respondents.

In the second set of analyses, members from task forces led by men also had lower commitment scores than women led and mixed gender led task forces, although this relationship was not significant $(\mathrm{E}(2,148)=2.81, \mathrm{p}=.06)$.

\section{Discussion}

This exploratory study found that leader gender was not related to member's perceptions of leadership style, the social climate of the group, or the satisfaction of group members. No statistically significant differences in perceptions of the task focus or interpersonal focus of the leaders was found, indicating that male and female leaders were perceived as having similar leadership styles. In addition, no statistically significant differences were found in the members' perceptions of the task focus of the task forces or in the inclusion/involvement of the task forces. Also, no differences were found among the satisfaction of the members from the different gender led task forces, indicating that female and male leaders had equally satisfied members in their organizations. These results support previous studies that also found no gender difference in these areas (i.e. Komives 1991, Eagly \& Johnson 1990).

No significant interaction effects of leader gender with respondent gender, or leader gender with gender composition of the group on any of the dependent variables 
were found in this study. This study did, however, find that the commitment of members differed across the different gender led groups. Although, this relationship was statistically significant only in one set of analyses.

In the set of analyses that used leader gender and respondent gender as independent variables, members from male led groups had significantly lower commitment scores than members from female led groups and mixed led groups. Another difference was also found in the same set of analyses. Male and female members differed in their levels of commitment, with women members reporting higher levels of commitment than men members. This is consistent with previous studies that found that women are more committed to an organization than men (i.e. Mathieu \& Zajac, 1990).

Although this study does not provide a test of any particular underlying theory, the results seem to provide some support for the structural perspective and the gender-role congruency theory. The male and female leaders in this study were equivalent in power and status, and performed similar functions. Thus, the fact that no gender differences were found in the perceived leadership styles of the leaders, in the social climate of the group, or in member satisfaction, provides some support for the structural theory. However, this theory is not entirely supported because of the difference found in the commitment of members across the different gender led groups. This relationship of commitment to the gender of the leader seems to support the gender-role congruency theory to the extent that one believes that leadership in voluntary organizations is congruent with a female gender role. However, again this theory is not fully supported because of the lack of differences found on the other variables.

The results of this study also indicate that the presence of one female leader influences a member's level of commitment since the male led groups were also different from mixed gender led groups which included one woman leader as either the coordinator or the chair of the group. These results suggest that female leaders may be doing 
something differently from male leaders that leads to different levels of commitment from their members.

What might female leaders be doing differently from male leaders? Are they leading in some way that is different from male leaders? This study found no differences in leadership style of male and female leaders. However, the assessment of leadership style in this study was done by 4 items, two that assessed perceptions of task focus and two that assessed perceptions of interpersonal focus. These items may not have been an adequate measure of leadership style. Instruments specifically designed to assess leadership style are composed of many more items (Stogdill, 1963). It is possible that differences may have existed between the leadership styles of the male and female leaders in this study, but that the instrument used was not sensitive enough to detect them.

Another explanation for the difference in commitment scores may be related to some characteristic of the group itself; and this characteristic may or may not be related to the gender of the leader. For example, it may be that groups with fewer members have more committed members, and that groups with fewer members tend to have female leaders. This study only examined two group characteristics, task focus and inclusion/cohesion, and no statistically significant differences were found among the different gender led task forces on these variables. However, other group characteristics not included in this study, such as group size, may also be related to the commitment of members, and may be related to leaders' gender.

The significant relationships with commitment in this study were found in the analysis using leader gender and respondent gender as independent variables. In the analysis using leader gender and gender composition of the group as independent variables, although the relationship between commitment and leader gender approached significance $(p=.06)$, no relationship between gender composition and commitment was found. This is surprising given the fact that the gender of the respondent was found to have a significant effect in the first set of analyses. One would have expected to find that 
groups composed of more men would have lower commitment scores than groups composed of more women, since men overall had lower commitment scores than women. However, this was not the case. These results indicate the complex nature of the findings and suggest that the relationships between gender and commitment may be very subtle and small.

The reason two sets of analyses were conducted instead of one was because the cell sizes were too small for three independent variables, indicating a shortcoming of the present study. Nevertheless, the results of this study are interesting given the current state of research in this area. Commitment, the only dependent variable that was found to have a significant relationship with leaders' gender, was also the only variable in this study that has generally not been studied in the literature on leadership and gender. In addition, this variable was also found to be significantly correlated with the other dependent variables that have frequently been studied in the literature. This suggests that this variable should be studied further in future research on the effects of leaders' gender.

Another reason why commitment should be included as a variable in future research on leadership, specifically research on voluntary groups, is because of its importance to voluntary organizations. Voluntary organizations rely on member participation; if members are not committed to a group, they won't participate in the group. Studies have found a relationship between member commitment and participation level and the effectiveness of the group (McMillan, Florin, Stevenson, Kerman, \& Mitchell, 1996).

A shortcoming to this study was the low response rate, $32 \%$. However, the respondents in this study represented the most active members of the task forces. These group members dedicated an average of 14 hours per month to task force activities and, as a group, the respondents attended over $70 \%$ of task force meetings held during the past year, on the average. Therefore, while the response rate was low, these respondents were highly active in their organizations and thus the best representatives of their task forces. 
A different issue that may have influenced the results of this study was the categorization of task forces with equal women and men members as having a majority of female members. However, this probably did not greatly affect the results because only 4 of the 32 task forces were categorized in this way.

One of the primary strengths of this study was the use of SAS Proc MIXED, which is a procedure designed to be a more sensitive test of differences across groups that contain nested data. Therefore, the fact that only one variable was different across the different gender led groups, and only in one set of analyses, indicates that male and female leaders are more similar on the other variables than they are different.

This study suggests that future research in the area of leadership and gender should include a measure of member commitment. Future research may also want to examine the relationship of organizational commitment and leadership gender with more comprehensive measures of leadership style and other measures of group characteristics. 


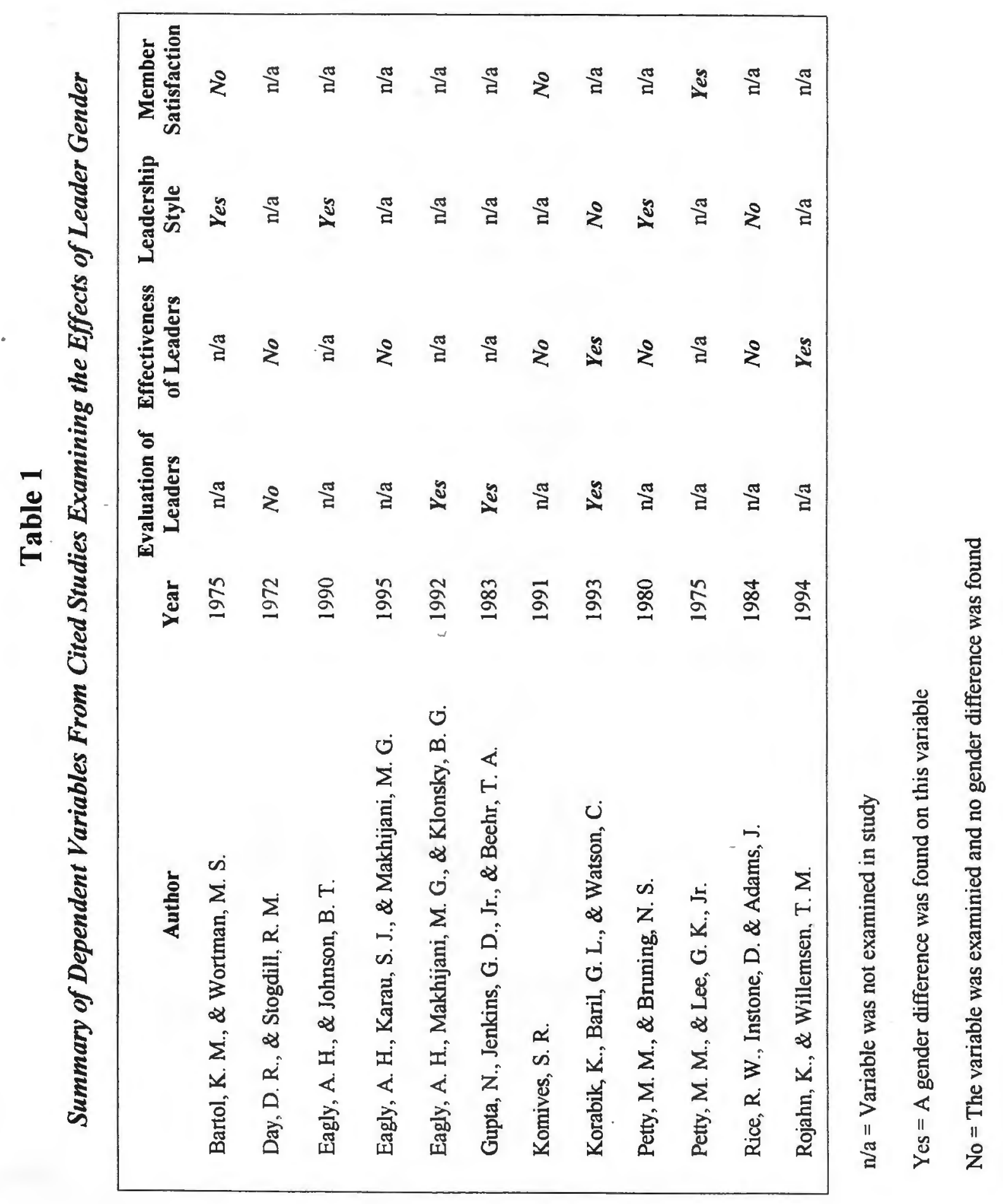




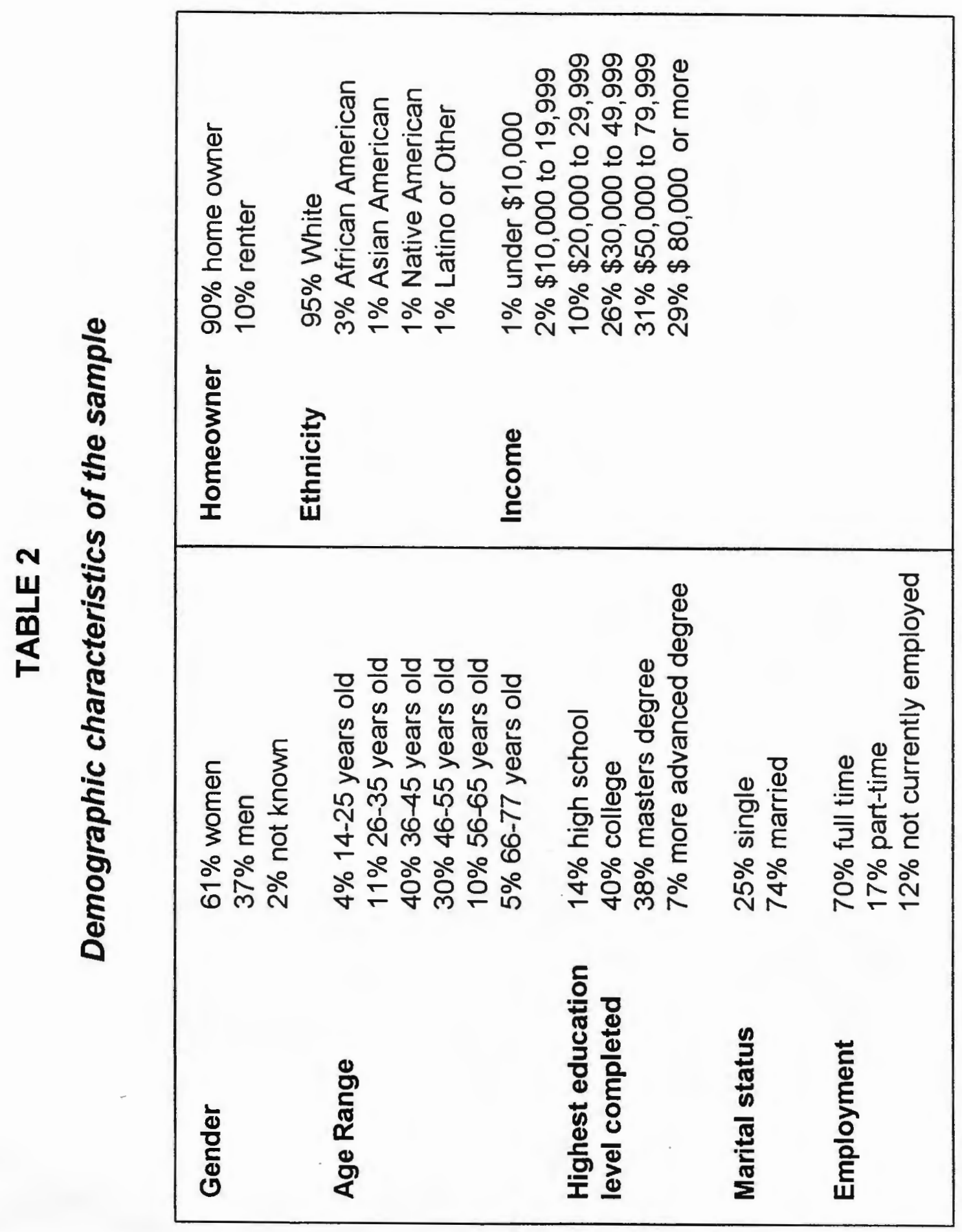




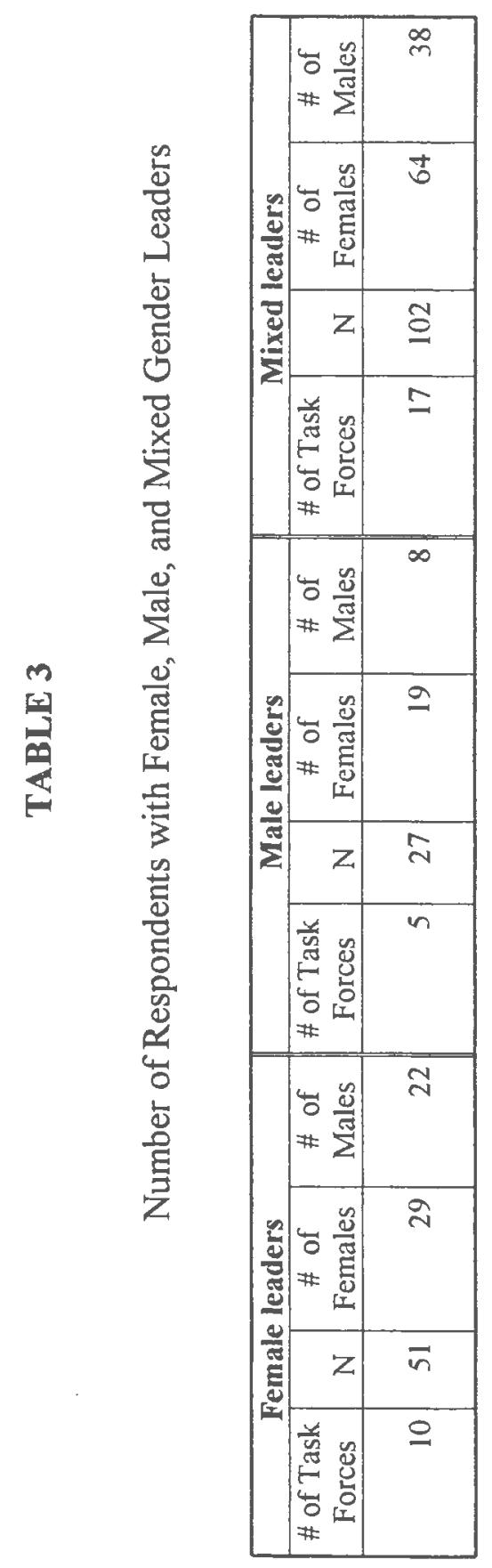




\section{Table 4}

Correlations Among the Dependent Variables

\begin{tabular}{|c|c|c|c|c|c|c|c|c|}
\hline & Tfcoor & Tfchair & Intchair & Intcoor & Taskfoc & Incluse & Satis & Commit \\
\hline Tfcoor & & $0.58^{* *}$ & $0.53^{* *}$ & $0.81^{* *}$ & $0.52^{* \star}$ & $0.62^{* *}$ & 0.56 ** & $0.49^{* *}$ \\
\hline Tfchair & $0.58 * *$ & & $0.76^{* *}$ & $0.48^{* *}$ & $0.61^{* *}$ & $0.55^{* *}$ & $0.48 * *$ & $0.41^{* *}$ \\
\hline Intchair & $0.76^{* *}$ & 0.76 ** & & $0.54^{* *}$ & $0.58 * *$ & $0.59^{* *}$ & $0.56^{* *}$ & $0.41^{* *}$ \\
\hline Intcoor & $0.48^{* *}$ & 0.48 ** & $0.54^{\star \star}$ & & $0.48^{* *}$ & $0.63^{* *}$ & $0.56^{* *}$ & $0.47^{* *}$ \\
\hline Taskfoc & 0.61 ** & 0.61 ** & $0.58 * *$ & 0.48 ** & & $0.71^{* *}$ & $0.74^{* *}$ & $0.53^{* *}$ \\
\hline Inclusc & $0.55^{* *}$ & $0.55^{* *}$ & 0.59 ** & $0.63^{* *}$ & $0.72^{* *}$ & & $0.73^{* *}$ & $0.58^{* *}$ \\
\hline Satis & $0.48^{* *}$ & 0.48 ** & $0.56^{* *}$ & $0.56^{* *}$ & $0.74^{* *}$ & $0.73^{* *}$ & & $0.61^{* *}$ \\
\hline Commit & 0.41 ** & 0.41 ** & 0.41 ** & 0.47 ** & $0.53^{\text {** }}$ & $0.58 * *$ & 0.61 * * & \\
\hline & & & & & & & & \\
\hline
\end{tabular}

** significant at .01 


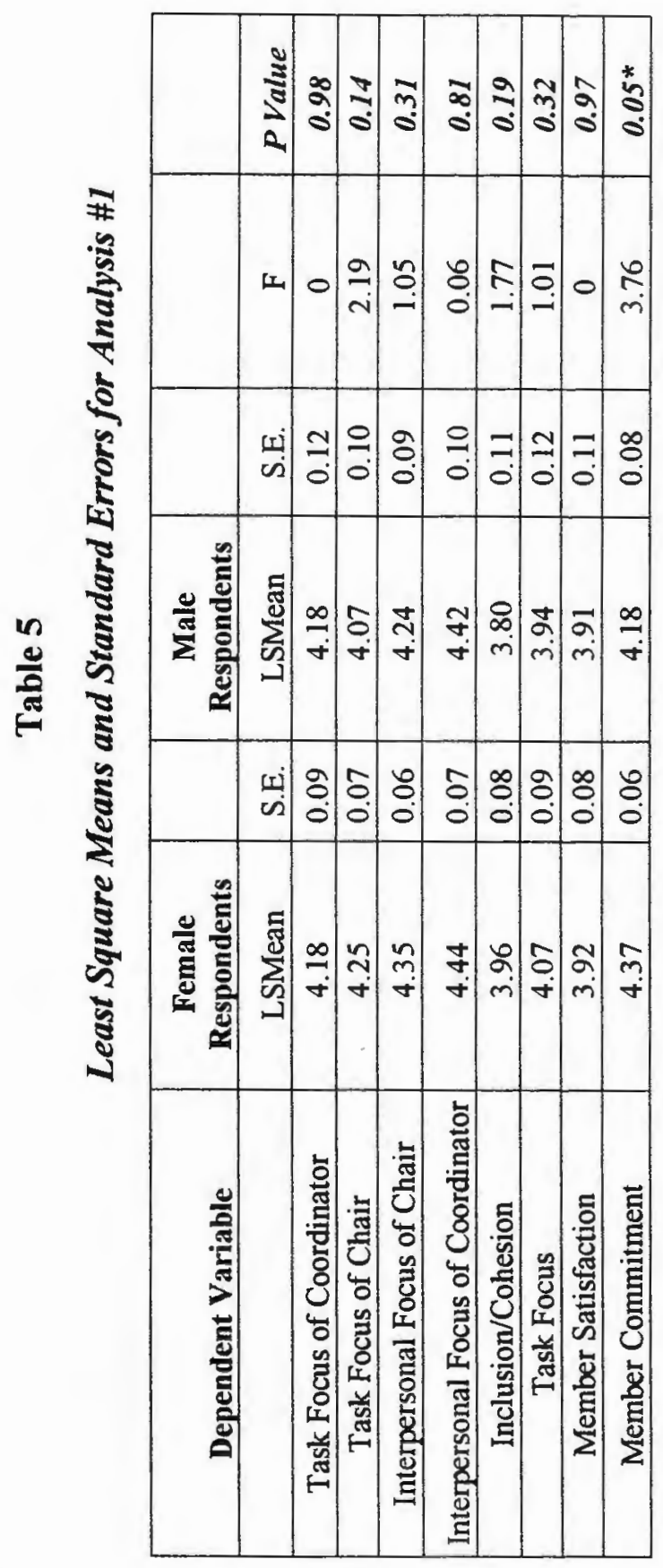

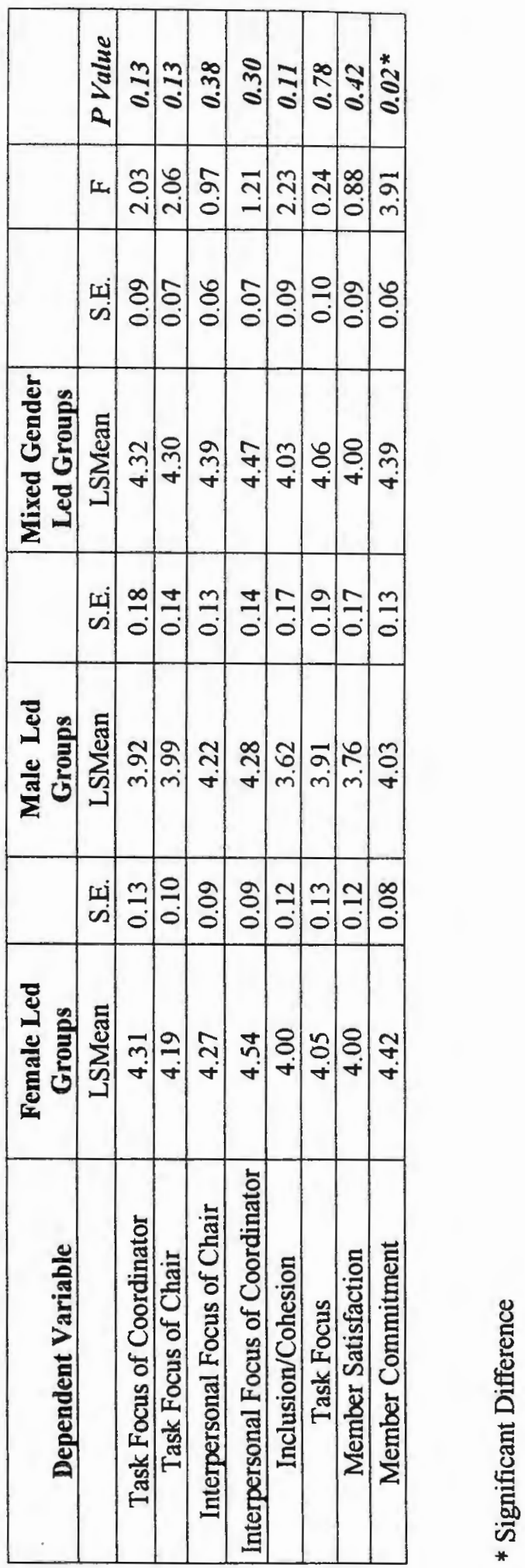




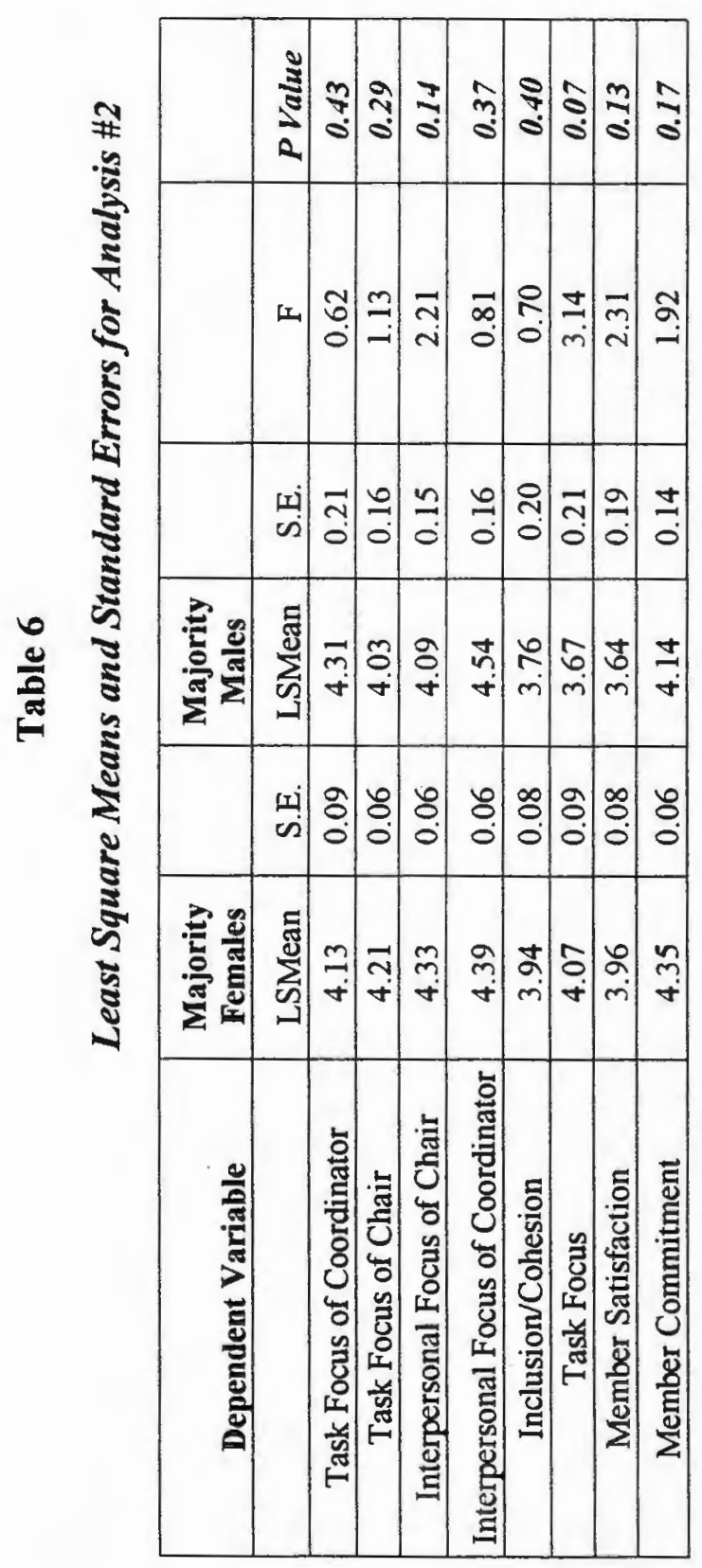

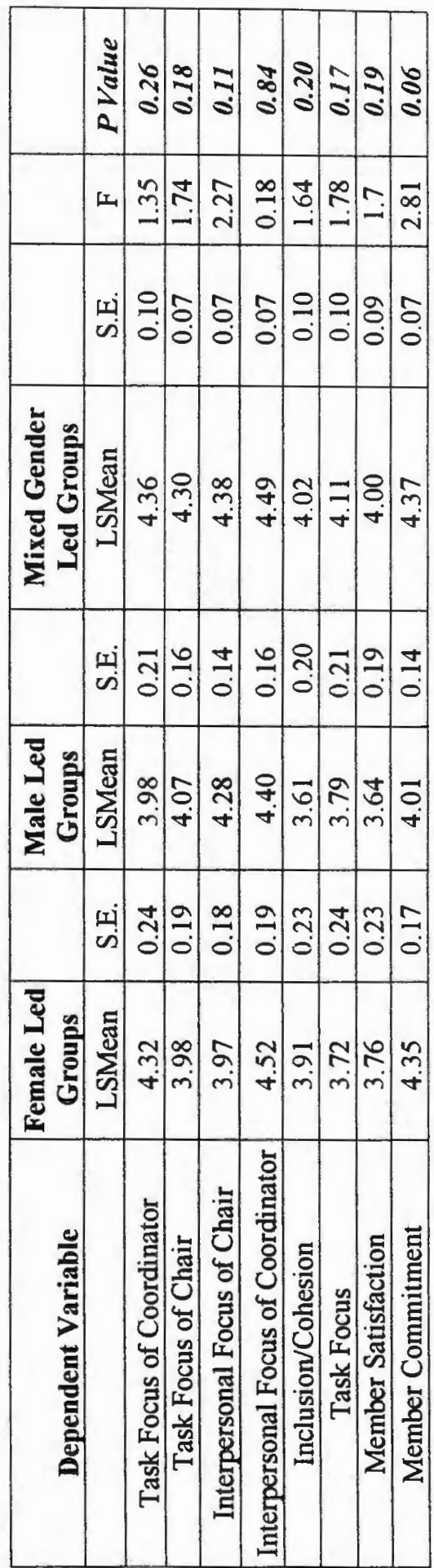

芯 


\section{LIST OF REFERENCES}

Aranya, N., Kushnir, T., \& Valency, A. (1986). Organizational commitment in a male-dominated profession. Human Relations, 39, 433-448.

Aven, F. F. Jr., Parker, B., \& McEvoy, G. M. (1993). Gender and attitudinal commitment to organizations: A meta-analysis. Journal of Business Research, 26, 63-73.

Bartol, K. M., \& Wortman, M. S. (1975). Male versus female leaders: Effects on perceived leader behavior and satisfaction in a hospital. Personnel Psychology, 28, 533-547.

Cooper, E. A., Doverspike, D., \& Barrett, G. V. (1985). Comparison of different methods of determining the sex type of an occupation. Psychological Reports, 57, 747-750.

Day, D. R., \& Stogdill, R. M. (1972). Leader behavior of male and female supervisors: A comparative study. Personnel Psychology, 25, 353-360.

Denmark, F. L. (1993). Women, leadership, and empowerment. Psychology of Women Quarterly, 17,343-356.

Eagly, A. H., \& Johnson, B. T. (1990). Gender and leadership style: A meta-analysis. Psychological Bulletin, 108, 233-356.

Eagly, A. H., Karau, S. J., \& Makhijani, M. G. (1995). Gender and the effectiveness of leaders: A meta-analysis. Psychological Bulletin, 117, 125-145.

Eagly, A. H., Makhijani, M. G., \& Klonsky, B. G. (1992). Gender and the evaluation of leaders: A meta-analysis. Psychological Bulletin, 111, 3-22.

Florin, P., Mitchell, R., \& Stevenson, J. (1993). Identifying training and technical assistance needs in community coalitions: A developmental approach. Health Education Research, 8, 417-432.

Graddick, M. M. \& Farr, J. L. (1983). Professionals in scientific disciplines: Sex-related differences in working life commitments. Journal of Applied Psychology, 68, $641-645$

Gupta, N., Jenkins, G. D., Jr., \& Beehr, T. A. (1983). Employee gender, gender similarity, and supervisor-subordinate cross-evaluations. Psychology of Women Quarterly, 8, 174-184. 
Klein, E. B., Kossek, E. E., \& Astrachan, J. H. (1992). Affective reactions to leadership education: An exploration of the same-gender effect. Journal of Applied and Behavioral Science, 28, 102-117.

Komives, S. R. (1991). The relationship of same and cross-gender work pairs to staff performance and supervisor leadership in residence hall units. Sex Roles, 24, 355-363.

Korabik, K., Baril, G. L., \& Watson, C. (1993). Manager's conflict management style and leadership effectiveness: The moderating effects of gender. Sex Roles, 29, 405-420.

Mathieu, J. E. \& Zajac, D. M. (1990). A review and meta-analysis of the antecedents, correlates, and consequences of organizational commitment. Psychological Bulletin, 108, 171-194.

McPherson, J. M., \& Smith-Lovin, L. (1986). Sex segregation in voluntary associations. American Sociological Review, 51, 61-79.

McMillan, B., Florin, P., Stevenson, J., Kerman, B., \& Mitchell, R. E. (1996). Empowerment praxis in community coalitions. American Journal of Community Psychology, 23, 699-728.

Mowday, R., Porter, L., \& Steers, R. M. (1982). Employee-Organizational Linkages. New York: Academic Press.

Murray, D. M., \& Wolfinger, R. D. (1994). Analysis issues in the evaluation of community trials: Progress toward solutions in SAS/STAT MIXED. Journal of Community Psychology, 140-154.

Petty, M. M., \& Bruning, N. S. (1980). A comparison of the relationships between subordinates' perceptions of supervisory behavior and measures of subordinates' job satisfaction for male and female leaders. Academy of Management Journal, $23,717-725$.

Petty, M. M., \& Lee, G. K., Jr. (1975). Moderating effects of sex of supervisor and subordinate on relationships between supervisory behavior and subordinate satisfaction. Journal of Applied Psychology, 60, 624-628.

Rice, R. W., Instone, D. \& Adams, J. (1984). Leader sex, leader success, and leadership process: Two field studies. Journal of Applied Psychology, 69, 12-31.

Rojahn, K., \& Willemsen, T. M. (1994). The evaluation of effectiveness and likability of gender-role congruent and gender-role incongruent leaders. Sex Roles, 30, 109-119. 
Stogdill, R. M. (1963). Manual for the Leader Behavior Description

Questionnaire-Form XII. Columbus, OH: Bureau of Business Research, Ohio State University. 
Appendix A 


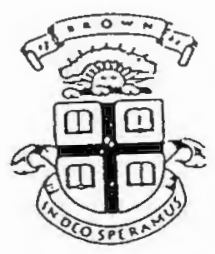

\author{
COMMUNITY RESEARCH AND SERVICES TEAM \\ CENTER FOR ALCOHOL AND ADDICIION STUDIES \\ BROWN UNTVERSTTY
}

\title{
COMMUNITIES UNITED FOR PREVENTION
}

\section{TASK FORCE MEMBER SURVEY}

Dear Task Force Member.

We would like your paricipation as we try to leam more about how to do a good job preventing alcohol and other dng (AOD) problems. This survey bas been mailed to all current and many former lask force members in Rhode Island. It asles about your participation on your community lask force, including questions about your prevention knowledge, skills and autitudes, your satisfaction with the task force and what changes you expect to see in your Task Force and your community as a result of Task Force efforts. This survey is par of a larger evaluation being conducted by the Community Research and Services Tearn. Cencer for Alcohol and Addiction Studies, Brown University.

Do net put your name on this survey. You will be asked to provide the last four digits of your social security number, which will be used co code the surveys. Since you will be asked to complete the suryey again in 1997 and 1998, this code will help us see bow things change over time. All information will be confidential to the extent of the law; we will be combining the information you give us with the responses of others in your task force. Your lask force will receive its own individualized profile compiled from respondents. We will also be combining the information across all task forces. However. ne communities will be identified in any public repert or document and this information cannot in any way, be used lo affect ans: individual task force's state funding level. Rather, the information will be used to improve our understanding of community prevencion and how to support it

This survey will probably take 20 or 25 minutes to complete. Your paricipation is completely voluntary. There are no known risks to taking par in this survey. You do not have to answer any questions that you do not wish to answer. Your answering the survey is taken as your consent to participate. Please respond within two weeks and recum the survey in the postage paid envelope provided, withour a return address. If you bave any questions about this survey, please feel free to contact Paul Florin. Pb.D. of the Community Research and Services Team. Center for Alcohol and Addiction Studies, Brown University at 4441810. If you have any concerns about the way this study was performed, or your rights as a research paricipant, call Alice $A$. Tangredi-Hannon or Dorinda Williams at 863-2777 at the Brown University Office of Research Administration.

Thank you for your belp!

Paul Florin

The Community Research and Services Tean

Center for Alcobol and Addicion Studies

Box G-BH

Brown University

Providence. RI 02912 
2. Are you currenty a member of the Task Force? YES NO

3. Are you currendy a voring member of the Task Force? YES NO

4. If no, how many months ago did you stop being a member? monchs

5. How many months have you been (or were you) a member of the Task Force? months

6. How many regular Task Force meelings were beld during the past 12 months? meelings

7. How many regular Task Force meetings did you attend over the pass 12 monchs? meetings

8. What kind of roles do YOU play (or did YOU play) in the community Task Force? Circle YES or NO after each.
a. Talk at meetings ( make comments. express ideas, etc.) YES NO
b. Serve as a nember of a committee YES NO
c. Do work for the Task Force outside of meetings YES NO
d. Help organize activities (other tban meeings). YES NO
e. Chair a commitcee YES NO
c. Chair the entire Task Force YES NO
g. Serve as a Task Force officer other than chair (e.g. treasurer, secretary) YES NO
h. Direct a particular program's implementacion YES NO
i. Serve in a paid capacity as Task Force coordinator YES
NO

9. In the average nnonth, about how many bours of your tine have you given to the Task Force in the following activities (please fill in number el hours for each activily).

a. hours for regular Task Force meecings.

b. hours for Task Force work outside of regular meetings (for example, attending activities, preparing for meetings or activities, paperwork)

c. Tolal Hours-may include other activities not mentioned above

10. In the average month, how many hours do you spend doing other voluntary community activities (besides dhe Task Force)? hours

11. Do you live in the community serverl by your linsk Force 
12. Is (or was) your paricipation in dic Task Force... (Circle a number wo the rigbt of your responsc.)

- Voluntary, uncompensated by any source. . .1

- Par of your job for an agency or organizacion that does nel reccive Task Force moncy...... 2

- Par or your job for an organization Urat reccives Task Force moncy (c.g. Contract for services).....

- As a dircet employec of Ule Task Force (c.g. paid coordinator). .4

13. A community Task Force may have members who come from many different community sectors, such as human service organizations, schools, parent groups, concemed cilizen, govemment, elc. What conmunity sector do you come from whose vicwpoint you offer (or offered) to the Task Force?

Community sector.

If you do nat represent any organization, and you are simply a concerned citizen, skip to Question \#18.

14. Participants on municipal Task Forces can "represent" the viewpoint of their organizztion or group in several ways. (PIease check only the one stacement that best describes your representation.)

_ Although I come from a particular organization or group. I "represent" only my own personal viewpoine while serving on the Task Force. (1)

$$
\begin{aligned}
& \text { - "represent" the official view- } \\
& \text { point of my own organization or } \\
& \text { group and report this to the Task } \\
& \text { Force. (2) }
\end{aligned}
$$

Other organizacions like mine express cheir viewpoint through me, therefore. I "represent" this community "sector" to the Task Force (3)

15. Do you have the authority to make decisions on bebalf of your organization or group at Task Force meecings? (check one)

- Yes(1). - - $\begin{aligned} & \text { Not without approval } \\ & \text { of ocher staff in my } \\ & \text { organization.(2) }\end{aligned}-\begin{aligned} & \text { Not without approval } \\ & \text { of my board or } \\ & \text { membersbip (3): }\end{aligned}$ Not at all (4)

16. Participation in a communicy Task Force may change relationships bedween erganizations or groups serving on ihe Task Eerce and ether organizations in the wider community. Please tell us the extent to which linkages between your organization or group and other organizations or groups not seoxing on the Task Force bas increased as a result of Task Force paricipation.

$\begin{array}{cccc}\text { no } & \text { minos } & \text { moderate } & \text { major } \\ \text { changes } & \text { increase } & \text { increase } & \text { increasc }\end{array}$

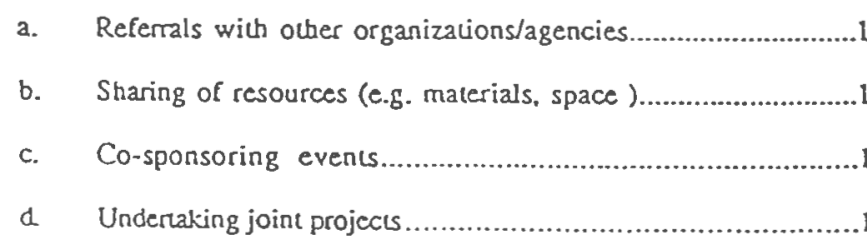

\section{1}

2

3

$\begin{array}{lll}2 & 3 & 4 \\ 2 & 3 & 4 \\ 2 & 3 & 4\end{array}$

17. With how many other organizations or groups nol serving on the Task Force is your organization now workina at an improved Icvel of contact and coordination as a result of paricipating in the community Task Force? Circle onc response.

$\begin{array}{llllll}0 & 1 & 2 & 3 & 4 & 5 \text { or more }\end{array}$


18. Below are several statements about your current participation (or former pareicipation) in che community Task Force. Curele the number 10 Uie right of each statement that shows bow much yous agree or disagnoc.

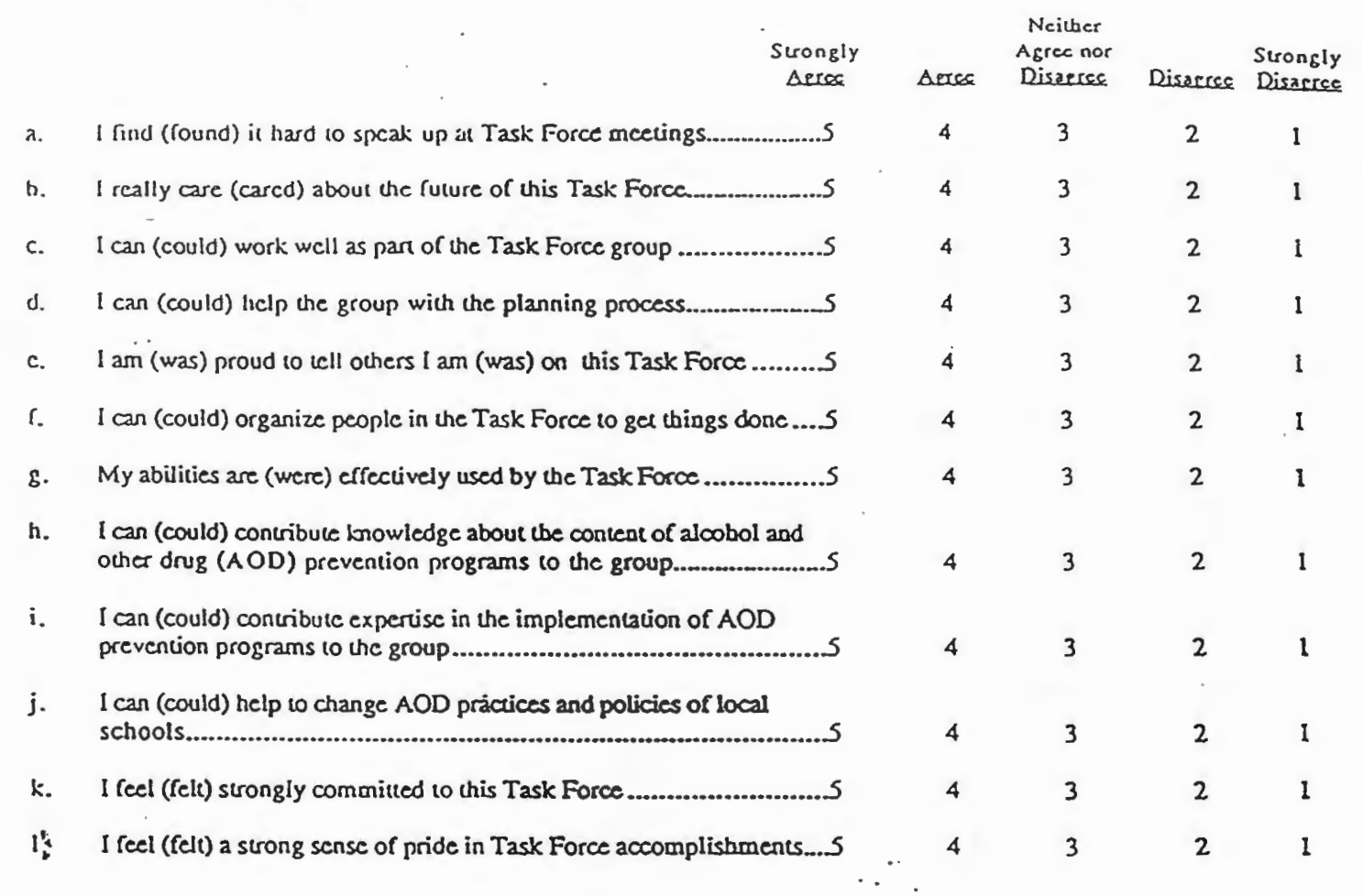

\section{THE EFFECTS OF YOUR PARTICIPATION}

19. Your paricipation in the Task Force may have changed your personal knowledge, beliefs or skills regarding AODA prevention. Please indicate the degree to which you feel each of the following has changed as a result of participating in the Task Ferce by circling a number to the right of each statement.

no minor moderate major
chenge increase increase increase

a. Knowledge of risk and procective factors for AOD problems

2

3

4

b. Knowledge of how different types of probleans (e.g. HIV, violence, ween pregnancy, and so on) may tave common risk (actors and causes

$\begin{array}{lll}2 & 3 & 4 \\ 2 & 3 & 4 \\ 2 & 3 & 4 \\ 2 & 3 & 4 \\ 2 & 3 & 4 \\ 2 & 3 & 4\end{array}$

b. Skills in changing local $\triangle O D$-rclated policies 
20. Below is a list of benelics you inay or may not gel (have gotten) (rom your involvement in your Task Force. Circle the number that describes how much of cacb benefil you are (or were) geaing from work with your Task Force.

\begin{tabular}{|c|c|c|c|}
\hline $\begin{array}{l}\text { very } \\
\text { onveb a } \\
\text { benctus }\end{array}$ & $\begin{array}{c}\text { somewbat } \\
\text { of a } \\
\text { lenclit }\end{array}$ & $\begin{array}{c}\text { not very } \\
\text { mucb of a } \\
\text { henefit }\end{array}$ & $\begin{array}{c}\text { nol } 28 \\
\text { all a } \\
\text { beneris }\end{array}$ \\
\hline
\end{tabular}

a. Gain suppor by worling with other members of the community ....................4

b. Gain personal recognition and respect from others....................................4

$3-2$

c. Leam new skills (public spcaking. program planning).................................4

32

d. Receive information about community services, events, alc ........................4

3

3

3

c. Provides a "sense of community" . .4

f. Fultills a sense of responsibility to contribute to the community . .4

3

21. You may also find that being on a Task Force causes (causod) some difficulties for you. Below is a list of difficulties which yeumay or may not have (had) because of your involvement in the Task Force. Circle the number that describes how much of cach difficulty you are (were) having because of work with your Task Force.

very
much
difficulisy

somewbat
of a
difficuliy

not very not at
mucb of a
difficuley difficully

a. Finding caregivers during meetings for family members (children, elderly) .....4

3

21

b. Demands too much of my personal tirric

3

2

\section{$\mathfrak{l}$}

c. Feeling that the Task Force never gets anything done

3

2

d. Feeling that the Task Force cannot really do much to prevent AOD problems.4

3

2

1

e. Feeling that the Task Force is not fully using my skills............................4.

f. Disagrecing personally with particular activities of the Task Force. 3

2

1

g. Feeling that 100 few people actually implement activities. . .4

21

212. Over the past 12 months what would you say the balance of the benefits of participation with the difficulties of participation was for you? (Circle the number that best represents your foelings).

\begin{tabular}{|c|c|c|c|c|}
\hline $\begin{array}{l}\text { benefits greatly } \\
\text { exceoded difficulties } \\
5\end{array}$ & $\begin{array}{c}\text { benefits excoeded } \\
\text { difficulties } \\
4\end{array}$ & $\begin{array}{c}\text { benefits oqualed } \\
\text { difficullies } \\
3\end{array}$ & $\begin{array}{c}\text { diffiallies excoded } \\
\text { benefits } \\
2\end{array}$ & $\begin{array}{l}\text { difficulties gready } \\
\text { excooded benefits } \\
1\end{array}$ \\
\hline
\end{tabular}

PLEASE TELL US A LITTLE ABOUT THE COMMUNITY SERVED BY YOUR TASK FORCE.

22. How much do you agree or disagree that this community is:

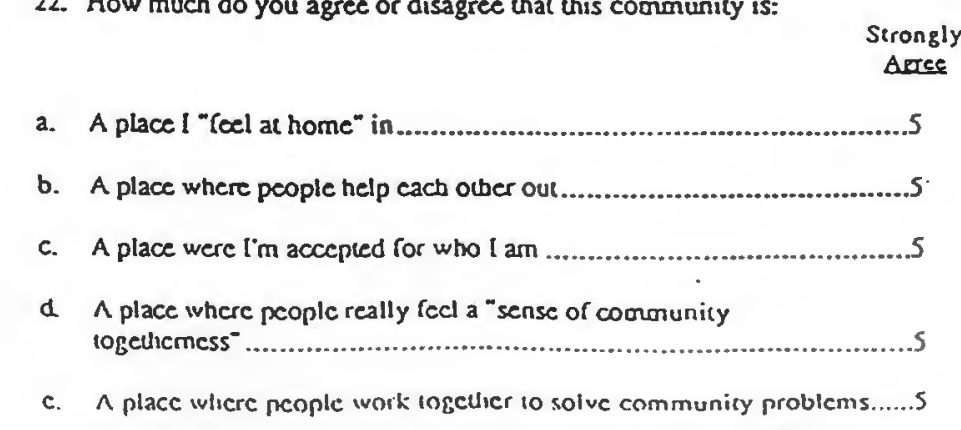

$\begin{array}{cc}\text { Neitber } & \text { Strongly } \\ \text { agrce nor } & \text { Disce } \\ \text { Disacree } & \text { Disacrec Disasree }\end{array}$

$\begin{array}{llll}4 & 3 & 2 & 1 \\ 4 & 3 & 2 & 1 \\ 4 & 3 & 2 & 1 \\ 4 & 3 & 2 & 1 \\ 1 & 3 & 2 & 1\end{array}$




\section{YOUR VIEIV OF TIDE COMMUNITY TASK FORCE AND ITS EFFECTS}

23. How satislied are you with cach of these aspects of the community Task Force? Sbow bow you fecl by circling a number to vie right of each of the salements.

Neitber
Very
Sactisfied Nor
*. The planning process used by the Task Force.
43

43
b. The writuen plan developed by the Task Force.... .5
c. The programs proposed to meel objeclives
4
3
2
2
1
a. The degree of member involvement with program

4

2

1
e. Overall Task Force functioning

43

3
c. Your personal experience as a Task Force paricipant

$2 \quad 1$
4
3
2

24. We'd like to know the way things run (or ran) in your Task Force Please indicate tbe degroe to which cach statement below describes the way your Task Force works (or worked) by circling a number to the right of each statement. If you have. trouble deciding. choose the answer that describes (described) your foelings moss of the time
a. The group has (had) a feeling of cobesiveriess and ream spiric
Strongly
$\frac{\text { Aeree }}{5}$
Neither
Agree oor
Disastec
$\frac{\text { Aree }}{4}$
$\begin{array}{cc}\text { Strongly } \\ \text { Disagrec } \\ 2 & \frac{1}{1}\end{array}$
b. Everyone is (was) involved in discussions, not just a few.

43
c. The purpose of agenda items is (was) defined and kepe in mind............
4
d. The Task Force is (was) disorganized and inefficient. $.5 \quad \cdot 4$
3
2
1

21
e. The general membership has (had) real decision making control over the policies and actions of the Task Force

.5

4

3

21
f. The group is (was) tolerant of differences or disagreements.

43
8. The Task Force uses (used) the abilities of all, not just a few.
h. The group needs (needed) more formatization and structure
i. The leader is (was) $100 "$ laissez faire" and not in control .....................
j. There is (was) too much takking and not enough doing .5

4

4
k. The Task Force provides (provided) opportunities for members to develop new skills... $\ldots 5$

4

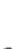
21
21

21
The members of this Task Force are (were) representative of the varied constitucncics of this community. .5
4

3

21

21

21

25. Overall, during the nasu lwelve monihs. would you say that your Task Force bas : (Please circle one number)
1. Gotten much suronger
2. Gollen suronger
3. Stayed about dic same
4. Gollen werker
5. Gorten mucli wcitici

Reason(s) why stronger or weaticr: 
26. Bclow are scveral statements about une paid coordinator who stafts your Task Force. and the chair of your Task Force (skin ue quescions aboul the coordinator if your Tast Force bas none). Please oonsider each stalcment dien cboosc tue ansucr drat cones closest to expressing your feeling. If you bave orouble dociding. cloose the answer that describes your foeliuns mess of the time.

A. The Coordinator...

(N/A - My Task Forec docsn't bave a coondinator)

(Skip to questions about The Chair)

- Slafis the Task Force in an orderly and efficicnt manner

- Respecis the skills that Task Force members already bave.

- Is open to fecdback from Task Force members

- Is too controlling of the Task Force.

B. The Chair..

(N/A - My Task Force doesn't bave a cbaiperson) (Skip to question 27)

Sirongly
Adece

5

5

\section{s}

$S$

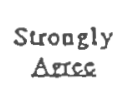

Anse

4

4

4

4
Neither

Agree nor

Disacree

$$
3
$$

3

3

3

Neitber

Agree nor

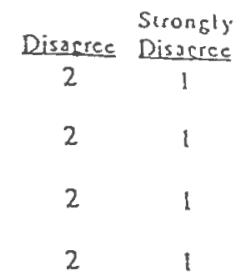

- Manages the Task Force in an orderly and efficient way

- Makes sure everyone is listened to in we meelings

54

43

\section{beres Disarree Disasce Disarres \\ beres Disarree Disasce Disarres}

- Is open to feedback from Task Force nembers

3

$\begin{array}{ll}2 & 1 \\ 2 & 1 \\ 2 & 1 \\ 2 & 1\end{array}$

1

- Is too controlling of the Task Force.

4

3

3

4

27. We'd like to know what effects you feel the existence of your Task Force bas had on the community. Please circle die number to the right of each statement lbat best represents bow trie you think each statement is.

The Task Force has:

b. Improved services and programs for AOD prevention in this community

c. Helped organizations working for prevenuion to increase their share of community resources.

d. Helped organizations working for prevention to increase tbeir joint infuence over community decisions.

e. Improved AOD-related policies in the community.............................

f. Improved AOD-related practices or policies of local schools................S

g. Helped local schools improve their prevention curriculum.

h. Increased the chance that children and youth will avoid developing AOD problems

i. Increased ability to work with groups concernce with preventing other rypes of probleons (c.g. HIV, violence, ceen pregnancy, elc.) .5

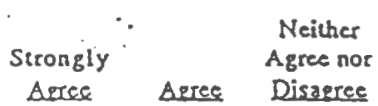

4

.5

.5

4

4

4

4

4

4

4

4
3

3

2

3

2

1

3

2 ।

Strongly

1

1

32

32

32

3

21

3

2


FOR SURHENT TASK FORCIE MEMUEUS ONLY. FOKMER MEMBERS ILEASE SKIT TO QUESTION HJO

28. Below is a list of acuvilies that you inight engage in as a member of your community Task Force. Show how likely it is you will do cach over une oess 12 monglus by circling a number to the right of each statement

$$
\text { Very Liliely Nor }
$$

a. I will allend Task Forec mecuings regulariy ............................... 4

b. I will devole time outside of mectings to the Task Force................... S 4

c. I will atempt 10 influence my group or organization to devote resources to increase community $A O D$ prevention activities.

d. I will altempl to increase linkages between my organization and other organizations to promolC AOD prevention activities.

(20.9)

29. Below is a list of potenvial accomplishments of your Task Force. Show bow likely you think cach is by circling a number to the right of each statement.

2. The Task Force will continue to expand and strengthen AOD prevention activities in the community Likely Nor Very Likely Likely Unlikely Unlikely Unlikely (1)

4

43

The Task Force will increase coordinaled AOD prevencion planning among community organizations...................................S

4

c. The Task Force will increasc its resources for prevention programming in this community

d. The Task Force will inluence local school AOD prevention policies and pracuices.

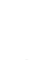

c. The Task Force will implement joint programs with groups concemed with preventing other types of problems than substance

f. The Task Force activities vill result in a decrease of AOD problems within the communily

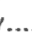

g. The Task Force will increase its influence over community decisions

\section{BACKGROUND INEORMATION}

Finally, would you please finish by answering a few background questions which will belp us describe community Task Force participants and analyze our results. Please check your response or fill in the appropriate number.
30. Age:
31. Malc or Fernale
32. Higbest grade or year of school completed:

33. Marital Status: _ not currently married _ married 34. Employment _full tine _part-time _not currendy employed

35. Number of people in your household under 18:

36. Homoowner or Renter

37. Racial group: _Alrican Ancrican _White _Asian _Native American _Latino Other:

$\begin{array}{llll}\text { 38. Houschold income froin all sourecs: } & \text { Under } \$ 10.000 & -\$ 10.000 \text { to } 19.999 & -\$ 20.000 \text { to } 29.999 \\ -\$ 30.0001049 .999 & -\$ 50.000 \text { to } 79.999 & -\$ 80.000 \text { or morc }\end{array}$

MHASL REVIFW TO ME SURE ALL QUISTIONS ARE ANSWERED. THANK YOU FOR YOUR COORERATION. 
Appendix B 


\section{Dependent Variables from the 1996 CUP Member Survey}

1. Perceptions of the Coordinator's task focus leadership style

- Staffs the Task Force in an orderly and efficient manner *

- Is too controlling of the Task Force *

2. Perceptions of the Coordinator's interpersonal leadership style

- Respects the skills that Task Force members already have *

- Is open to feedback from Task Force members*

3. Perceptions of the Chair's task focus leadership style

- Staffs the Task Force in an orderly and efficient manner *

- Is too controlling of the Task Force *

4. Perceptions of the Chair's task focus leadership style

- Respects the skills that Task Force members already have *

- Is open to feedback from Task Force members *

5. Involvement/inclusion in the Task Force

- The group has/had a feeling of cohesiveness and team spirit

- Everyone was/is involved in discussions, not just a few

- The general membership has/had real decision making control over policies and actions of the Task Force

- The group was/is tolerant of differences or disagreements

- The Task Force uses/used the abilities of all, not just a few

\section{Perceptions of Task Focus}

- The purpose of agenda items is/was defined and kept in mind

- The Task Force is/was disorganized and inefficient

- The group needs more formilization and structure

- There was too much talking and not enough doing

7. Satisfaction of members

- The planning process used by the Task Force

- The programs proposed to meet objectives

- The written plan developed by the Task Force *

- The degree of member involvement with program implementation

- Overall Task Force functioning

- Your personal experience as a Task Force participant *

* indicates a new item in this version of the survey 
8. Commitment to the Task Force

- I really care about the future of the Task Force

- I am/was proud to tell others I am/was on the Task Force

- I feel strongly committed to the Task Force

- I feel a strong sense of pride in Task Force accomplishments 


\section{BIBLIOGRAPHY}

Aranya, N., Kushnir, T., \& Valency, A. (1986). Organizational commitment in a male-dominated profession. Human Relations, 39, 433-448.

Aven, F. F. Jr., Parker, B., \& McEvoy, G. M. (1993). Gender and attitudinal commitment to organizations: A meta-analysis. Journal of Business Research, 26, 63-73.

Bartol, K. M., \& Wortman, M. S. (1975). Male versus female leaders: Effects on perceived leader behavior and satisfaction in a hospital. Personnel Psychology, $28,533-547$.

Cooper, E. A., Doverspike, D., \& Barrett, G. V. (1985). Comparison of different methods of determining the sex type of an occupation. Psychological Reports, 57, 747-750.

Day, D. R., \& Stogdill, R. M. (1972). Leader behavior of male and female supervisors: A comparative study. Personnel Psychology, 25, 353-360.

Denmark, F. L. (1993). Women, leadership, and empowerment. Psychology of Women Quarterly, 17,343-356.

Eagly, A. H., \& Johnson, B. T. (1990). Gender and leadership style: A meta-analysis. Psychological Bulletin, 108, 233-356.

Eagly, A. H., Karau, S. J., \& Makhijani, M. G. (1995). Gender and the effectiveness of leaders: A meta-analysis. Psychological Bulletin, 117, 125-145.

Eagly, A. H., Makhijani, M. G., \& Klonsky, B. G. (1992). Gender and the evaluation of leaders: A meta-analysis. Psychological Bulletin, 111, 3-22.

Florin, P., Mitchell, R., \& Stevenson, J. (1993). Identifying training and technical assistance needs in community coalitions: A developmental approach. Health Education Research, 8, 417-432.

Graddick, M. M. \& Farr, J. L. (1983). Professionals in scientific disciplines: Sex-related differences in working life commitments. Journal of Applied Psychology, 68, 641-645

Gupta, N., Jenkins, G. D., Jr., \& Beehr, T. A. (1983). Employee gender, gender similarity, and supervisor-subordinate cross-evaluations. Psychology of Women Quarterly, 8, 174-184. 
Klein, E. B., Kossek, E. E., \& Astrachan, J. H. (1992). Affective reactions to leadership education: An exploration of the same-gender effect. Journal of Applied and Behavioral Science, 28, 102-117.

Komives, S. R. (1991). The relationship of same and cross-gender work pairs to staff performance and supervisor leadership in residence hall units. Sex Roles, 24, $355-363$

Korabik, K., Baril, G. L., \& Watson, C. (1993). Manager's conflict management style and leadership effectiveness: The moderating effects of gender. Sex Roles, 29, 405-420.

Mathieu, J. E. \& Zajac, D. M. (1990). A review and meta-analysis of the antecedents, correlates, and consequences of organizational commitment. Psychological Bulletin, 108, 171-194.

McPherson, J. M., \& Smith-Lovin, L. (1986). Sex segregation in voluntary associations. American Sociological Review, 51, 61-79.

McMillan, B., Florin, P., Stevenson, J., Kerman, B., \& Mitchell, R. E. (1996). Empowerment praxis in community coalitions. American Journal of Community Psychology, 23, 699-728.

Mowday, R., Porter, L., \& Steers, R. M. (1982). Employee-Organizational Linkages. New York: Academic Press.

Murray, D. M., \& Wolfinger, R. D. (1994). Analysis issues in the evaluation of community trials: Progress toward solutions in SAS/STAT MIXED. Journal of Community Psychology, 140-154.

Petty, M. M., \& Bruning, N. S. (1980). A comparison of the relationships between subordinates' perceptions of supervisory behavior and measures of subordinates' job satisfaction for male and female leaders. Academy of Management Journal, $23,717-725$.

Petty, M. M., \& Lee, G. K., Jr. (1975). Moderating effects of sex of supervisor and subordinate on relationships between supervisory behavior and subordinate satisfaction. Journal of Applied Psychology, 60, 624-628.

Rice, R. W., Instone, D. \& Adams, J. (1984). Leader sex, leader success, and leadership process: Two field studies. Journal of Applied Psychology, 69, 12-31.

Rojahn, K., \& Willemsen, T. M. (1994). The evaluation of effectiveness and likability of gender-role congruent and gender-role incongruent leaders. Sex Roles, 30, 109-119. 
Stogdill, R. M. (1963). Mamual for the Leader Behavior Description Questionnaire-Form XII. Columbus, $\mathrm{OH}$ : Bureau of Business Research, Ohio State University. 